\title{
Textile and Apparel Barriers and Rules of Origin: What's Left to Gain after the Agreement on Textiles and Clothing?
}

\author{
Alan K. Fox \\ U.S. International Trade Commission \\ William Powers \\ U.S. International Trade Commission \\ Ashley Winston \\ Monash University \\ U.S. International Trade Commission
}

\begin{abstract}
Although textile and apparel imports from most countries entered the United States quota-free after the expiration of the Agreement on Textiles and Clothing on January 1, 2005, substantial restraints remain on U.S. trade in these sectors, including high tariffs, quantitative restraints on China and Vietnam, and preferential rules of origin. While there is a substantial literature on liberalization of quotas and tariffs in these sectors, this paper provides a new and detailed examination of the effects of rule-based foreign demand for U.S. textile and apparel inputs. This paper uses the USAGE-ITC general equilibrium model to estimate the effects of removing textile and apparel restraints in 2005. Full liberalization is estimated to increase U.S. welfare by $\$ 2.0$ billion (net) while decreasing U.S. textile and apparel output by 9.0 percent. Quantitative restraints continue to have considerable effects on U.S. welfare: their

*Alan K. Fox: Research Division, Office of Economics, U.S. International Trade Commission, 500 E Street SW, Washington, DC 20436, Tel: (202) 205-3267, Fax: (202) 205-2340, E-mail: Alan.Fox@usitc.gov, William Powers: Corresponding author: U.S. International Trade Commission, Tel: (202) 708-5405, Fax: (202) 205-2340, E-mail: william.powers@usitc.gov, Ashley Winston: Center of Policy Studies, Monash University, Wellington Road, Clayton Victoria 3800, Australia, E-mail: ashley.winston@ buseco.monash.edu.au

(C2008-Center for International Economics, Sejong Institution, All Rights Reserved.
\end{abstract}


elimination provides over half of the welfare gain. However, rules of origin have by far the largest effect on production and employment. Elimination of preferential rules of origin accounts for 82 percent of the overall output reduction, because these rules currently generate nearly half of the foreign demand for U.S. textile and apparel exports. A similarly large output loss would also be part of any tariff liberalization that encouraged preferential trade partners to reduce purchases of U.S. inputs as their preference margins eroded. This is the first study in the literature to quantify this effect, which is sufficient to eliminate four-fifths of the welfare gains from tariff liberalization in these sectors.

- JEL classification: C68, D58, F13, F14, F17

- Key words: international trade, U.S. textiles and apparel trade, rules of origin, computable general equilibrium models, forecasting and policy analysis

\section{Introduction}

Trade in textiles and apparel in the United States has been subject to quantitative restriction since the 1960s, most notably under the terms of the Multifibre Arrangement (MFA, 1974-1994) and its successor, the Agreement on Textiles and Clothing (ATC, 1995-2005), established as part of the Uruguay Round negotiations. ${ }^{1}$ The ATC set as its goal the orderly elimination of quantitative restraints in textiles and clothing. These restraints were eliminated on January 1, 2005, although countries remain free to impose quotas on non-WTO countries.

Although the ATC achieved the most important liberalization of these products since the 1960s, textile and apparel products remain subject to some of the most restrictive import barriers in the United States economy. Three important types of trade restraints remained in these sectors after 2005. First, although most quotas expired with the ATC, substantial quantitative restraints remained for imports from China and Vietnam. ${ }^{2}$ These countries were respectively the first and eighth largest exporters of textiles and apparel to the United States, so quantitative restraints remained important barriers to U.S. imports. Second, the expiration of the ATC did not affect textile or apparel tariff rates, which were among the highest of any U.S.

${ }^{1}$ See Spinanger (1999) for a detailed description of the development and demise of the Multifibre Agreement and the ATC.

${ }^{2}$ The Vietnamese quotas were eliminated upon its accession to the WTO on January 11, 2007. 
product sector. ${ }^{3}$ Third, preferential rules of origin (RoO), which require eligible foreign trade partners to use U.S. or regional yarn and fabric inputs to qualify for duty-free access to the U.S. market, had a very large effect on U.S. exports and production. These rules applied to the 28.0 percent of U.S. textiles and apparel that were imported duty-free from preferential trading partners, and they generated over half of U.S. apparel exports in 2005.

There are a number of papers that have estimated the welfare effects of tariffs and quantitative restraints in textile and apparel sectors in the eras of the MFA and ATC. These studies have consistently found that import barriers reduced U.S. welfare by at least $\$ 10$ billion dollars. We use detailed 2005 data on tariffs and quantitative restraints on Chinese and Vietnamese imports and estimate that the welfare cost of the remaining barriers was about $\$ 2.7$ billion dollars, indicating that the ATC has dramatically, though not completely, liberalized the U.S. textile and apparel market. We also show that the majority of this welfare cost comes from the remaining quantitative restraints, which will be completely eliminated by the end of 2008 .

However, the earlier studies do not incorporate a crucial feature of the U.S. textile and apparel market, namely preferential RoO. Given the prominence of duty-free imports and the dominant share of preferential trading partners in U.S. exports, a careful consideration of the effects of RoO is important to quantify the effects of further liberalization. We contribute to the literature by quantifying the effect of RoO on foreign demand for U.S. textile inputs for the most important sectors and preferential trading partners. We then incorporate these estimates of RoO-driven foreign demand in our liberalization exercise and find that the reduction in foreign demand would reduce the welfare gains of liberalization by about 25 percent, to $\$ 2.0$ billion. The incorporation of foreign demand also gives much larger and more realistic estimates of the reduction in U.S. output and employment resulting from liberalization. This paper makes the most comprehensive examination to date of the effect of preferential textile and apparel RoO on trade, production, and national welfare.

The discussion below is focused on the textile and apparel sectors in the model. While the USAGE-ITC is a fully-specified dynamic CGE model with over 500 sectors, a detailed analysis of every model sector is beyond the scope of this paper. The textile and apparel sectors comprise a relatively small part of the U.S.

\footnotetext{
${ }^{3}$ The trade-weighted average tariff rate in these sectors was 9.4 percent in 2005. USITC (2007) lists only the footwear, dairy, and canned tuna sectors as having higher tariffs.
} 
economy, with the total output loss in this sector from the full-liberalization scenario representing less than 0.1 percent of 2011 U.S. GDP, the net change in GDP being 0.005 percent, and the terms of trade effect being only 0.05 percent. The effects on other sectors of the economy are consequently quite modest.

This paper is organized as follows. The remainder of section I compares the literature on textile and apparel trade restraints to our results. Section II quantifies the restrictiveness of quantitative restraints, tariffs, and $\mathrm{RoO}$, which provide price and quantity shocks for the liberalization scenario. Section III describes the model, and Section IV provides estimates of changes in welfare and sectoral activity from liberalizing the barriers quantified in Section II. This section also contrasts the welfare and sectoral impacts of liberalizing quantitative restraints, tariffs, and RoO separately. Section V Concludes.

\section{Literature Review}

This paper is related to two strands in the literature. The first strand is represented by the estimation of welfare effects from liberalization of tariffs and quantitative restraints in textile and apparel sectors, surveyed by Walkenhorst (2005). An early example of a computable general equilibrium (CGE) analysis is de Melo and Tarr (1990), which estimates that quotas reduced U.S. welfare by $\$ 18.0$ billion in 1984. Reinert (1993) estimates that MFA quotas reduced U.S. welfare by $\$ 7.3$ billion. Periodic U.S. International Trade Commission (USITC) estimates of potential welfare gains from textile and apparel liberalization (including both quotas and tariffs) have similar magnitudes to the earlier studies: \$7.4-11.3 billion in 1993, $\$ 10.4$ billion in 1996, $\$ 13$ billion in 1999, and \$9-14 billion in 2002. ${ }^{4}$ Our estimates in this paper show that the removal of quantitative restraints and tariffs would increase welfare by 2.7 billion dollars, or about 20-25 percent of the value of estimates made before the expiration of the ATC.

Walmsley and Hertel (2001) examine the welfare effects of textile and apparel safeguards permitted in China's accession agreement to the WTO. They find that delaying the elimination of quantitative restraints on Chinese exports would reduce North American welfare. Our paper supports that finding and estimates that the imposition of U.S. safeguards on Chinese exports in 2005 reduced U.S. welfare by $\$ 896$ million. In addition, we find that U.S. quotas on Vietnamese exports in 2005

${ }^{4}$ See USITC (1995, 1999a, 2002, and 2004). Chapter 3 of USITC (2007) contains an earlier version of this paper. 
reduced U.S. welfare by a similar amount.

The second strand in the literature related to this paper concerns the prevalence, costs, and benefits of preferential $\mathrm{RoO}$, which generally require preferential trade partners to use of U.S. or regional textile inputs in imported duty-free apparel. The U.S. content contained in preferential imports had been detailed in a series of USITC reports on production sharing, which was the principle provision for reduced-duty imports prior to the rise of NAFTA and regional duty-free preferences. These reports ended with USITC (1999b). Our paper appears to be the only recent paper to estimate the value of U.S. content in RoO-driven imports and exports for key sectors and trading partners. ${ }^{5}$

There is also research on the compliance costs of RoO, which concludes that textile and apparel $\mathrm{RoO}$ have higher costs than RoO in other sectors. Carrère and de Melo (2004) estimate that the average NAFTA compliance cost in 2001 was 9.2 percent in these sectors, close to the average textile and apparel tariff preference rate of 10.4 percent. Cadot et al. (2005) conclude that RoO compliance costs are a smaller share of the preference margin; they estimate that Mexican producers retain half of the preference, and most of these gains are spent complying with RoO. In comparison to other sectors, Anson et al. (2005) note that textiles and apparel have slightly belowaverage utilization rates but higher than average RoO restrictiveness, implying that the costs of RoO in textiles and apparel are higher than average. RoO compliance costs for trade agreements other than NAFTA have not been estimated in the literature, and such calculation is outside the scope of this paper. Our examination of 2005 unit values, as discussed in Section II.A.3, reveals that the unit value of exporting from preferential trade partners to the United States relative to other OECD countries has fallen since 2001, which is suggestive of reduced RoO compliance costs.

\section{Restrictiveness of U.S. Import Restraints}

This section quantifies the restrictiveness of U.S. preferential RoO, quantitative restraints, and tariffs. Each type of restraint is discussed in detail below. These estimates are used as inputs in the USAGE-ITC CGE model in Section IV to examine the effects of these restraints on U.S. welfare and textile and apparel production, employment and trade.

\footnotetext{
${ }^{5}$ The International Trade Administration's Office of Textiles and Apparel reports imports and exports by trade partner and product, and reports preferential imports for specific RoO, but it does not concord these values or report the U.S. content of this trade.
} 


\section{A. Rules of Origin}

The prevalence of duty-free textiles and apparel imports highlights the importance of accounting for RoO in any analysis of trade liberalization. In most textile and apparel sectors, duty-free imports must fulfill certain $\mathrm{RoO}$ criteria that require the use of U.S. or regional fabric or yarn. RoO are influential in directing trade flows because they create demand for U.S. exports of textile articles for use in the production of apparel, which is then re-exported to the United States free of duty.

Although some aspects, such as production sharing provisions, are common to many products and agreements, in general RoO differ markedly by product and by U.S. trading partner. Across products, RoO have the greatest effect on foreign demand for U.S. apparel, fabric, and yarn, but have little effect on most textile products. ${ }^{6}$ Across trade partners, although the United States granted preferential access to dozens of countries in 2005, most trade occurred with Mexico, Canada, Andean countries eligible for the Andean Trade Promotion and Drug Eradication Act (ATPDEA), and Central American and Caribbean countries eligible for the Caribbean Basin Trade and Partnership Act (CBTPA). ${ }^{7}$ These countries received 95.3 percent of U.S. textile and apparel exports to all preferential trading partners, or 74.7 percent of total U.S. exports of these goods. ${ }^{8}$

Estimating the effect of textile and apparel liberalization on the United States requires estimates of the foreign demand generated by preferential RoO by sector and trade partner. These data are not generally available. However, we can estimate U.S. sectoral exports under these programs if we can accurately assess the U.S. content of imports under these programs. This is the task we turn to next.

\section{Estimating the U.S. Content of U.S. Imports}

Imports under FTAs and preference programs enter under the following

\footnotetext{
${ }^{6}$ We thank Kim Freund for encouraging us to begin this investigation of textile and apparel RoO by highlighting the implausible results of simulations that exclude them. We thank Andrea Boron for valuable assistance identifying $\mathrm{RoO}$ sectors.

${ }^{7}$ CBTPA consists of Barbados, Belize, Costa Rica, the Dominican Republic, El Salvador, Guatemala, Guyana, Haiti, Honduras, Jamaica, Nicaragua, Panama, St. Lucia, and Trinidad and Tobago. ATPDEA consists of Bolivia, Colombia, Ecuador, and Peru.

${ }^{8}$ The following are the largest suppliers of duty-free imports: NAFTA countries (36.0 percent of the total), CBTPA countries (25.7 percent), African Growth and Opportunity Act countries (5.5 percent), and ATPDEA countries (5.1 percent). Goods entered under the production-sharing provisions of HTS chapter 98 accounted for an additional 18.4 percent of the duty-free value.
} 
provisions: (a) production-sharing provisions, for which the value of U.S. content is declared to Customs; (b) RoO that require specific U.S. inputs, for which we estimate U.S. content for the specified inputs; (c) RoO that do not require U.S. inputs, for which we assume no U.S. content; and (d) non-preferential MFN tariff rates, for which we assume no U.S. content. Each of these provisions differ by product and program. We highlight the nature of these provisions, and calculate U.S. content for specific trading partners below.

Production sharing provisions allow goods manufactured or assembled in foreign plants using U.S. parts to be imported with tariffs applied only to the value added abroad. These imports enter under customs heading 9802 of the U.S. harmonized tariff schedule (HTS), and customs reports both the value of the U.S. content of imports and the regular (i.e., non-9802) HTS code of the imported product.

A significant portion of preferential imports with U.S. content do not enter under HTS 9802 because the goods are eligible for duty-free treatment under other agreements. There is good information about U.S. content in these imports under ATPDEA and CBTPA, because preferential imports must enter under specific HTS codes that specify the type of inputs allowed for duty-free access. ${ }^{9}$ We estimate U.S. content of fabric and yarn inputs in these imports using the commodity cost shares of inputs in apparel production from the model's U.S. input-output table.

There is less information about the U.S. content in preferential trade with NAFTA. The share of imports under HTS 9802 from NAFTA declined after January 1, 1999 because most apparel imports became duty free under NAFTA on that date. ${ }^{10}$ The value of the imports that enter duty-free under NAFTA is known but the U.S. content is not. We used the share of U.S. value in imports from the 1998 imports under HTS 9802 to estimate the U.S. share of the 2005 duty-free nonproduction-sharing imports under NAFTA. The 1998 share was used instead of the 2005 share because the share of U.S. value in production-sharing imports become more variable as these imports became less common (and likely less representative) after the 1999 NAFTA duty changes, while the overall ratio of U.S. exports to U.S. imports remained steady during this period.

The last two types of imports contain much less U.S. input. Some preferential

${ }^{9}$ For example, imports from ATPDEA under HTS 9820.11.12 consist of T-shirts with U.S. yarn but nonU.S. fabric; and imports under HTS 9820.11 .03 consist of fabrics formed, cut, and finished in the United States, from yarns formed in the United States.

${ }^{10}$ The description of production sharing provisions is from USITC (1999b). 
provisions do not require U.S. inputs. This type of import is much more common from Canada than from Mexico, perhaps reflecting lower overall textile market integration. These imports are also more common from Andean countries than from Caribbean countries because of differences in preferential RoO between the programs. We assumed these imports had no U.S. content. The final type of import utilizes no preference program and enters under MFN rates. We assumed these imports also had no U.S. content.

\section{Estimating Foreign Demand for U.S. Inputs}

The total value of exports of U.S. inputs must be equal to the total U.S. value embodied in U.S. imports. ${ }^{11}$ However, this need not be true for individual sectors, because the sectors in which the U.S. imports the goods may differ from the sector in which goods are exported. The match between import and export sector differs by partner and RoO. In general, the specificity of ATPDEA and CBTPA preferential RoO allow a good determination of the sector of export of U.S. inputs. ${ }^{12}$ For NAFTA countries, however, there is less information, and the U.S. content contained in preferential imports of apparel exceeded the U.S. exports of apparel. The excess was allocated to textile mill sectors using the commodity cost shares of these inputs into apparel.

The estimated export demand is presented as a share of total U.S. exports by sector and trading partner in Table 3. These shares will be the demand reductions we will apply in our liberalization simulation in Section IV. Comparing the implied demand reduction across trading partners, we see that nearly all U.S. exports of apparel and textile mill articles to ATPDEA and CBTPA countries are driven by RoO. The only exceptions are broad fabric and narrow fabric, which are not given duty-free status under preferential RoO but are imported under the production sharing agreements. RoO-driven demand in Canada and Mexico covers many more sectors, reflecting greater eligibility for duty-free access under NAFTA. Also, there is less reduction in the textile mill sectors, particularly for Canada. It may be that more of the U.S. content in the apparel sectors should be applied to textile inputs. However, the large apparel reduction is consistent with the other trading partners,

\footnotetext{
${ }^{11}$ We ignore the price wedge created by the RoO themselves. See the discussion in section 2.1.3 concerning lower compliance costs in 2005 relative to previous estimates in the literature.

${ }^{12}$ Those familiar with ATPDEA and CBTPA RoO may wonder why broad fabric exports under these programs contain U.S. inputs, when RoO chiefly provide duty-free access for knit fabric. U.S. broad fabric exports serve as inputs to apparel produced under production-sharing agreements.
} 
and this should not greatly affect the liberalization results, because the total NAFTA demand reduction in all sectors should be correct and exports to Canada of textile inputs are not a large share of total exports of these products.

\section{Compliance Costs of RoO}

As noted in the introduction, RoO can have high compliance costs, particularly for apparel products which face the most restrictive types of RoO. These costs are passed along to U.S. consumers when they buy imports from preferential trading partners. No studies exist that estimate compliance costs by detailed sector and trading partner. Carrère and de Melo (2004) find that NAFTA compliance costs in 2001 were substantial in a number of sectors. Estevadeordal and Suominen (2006) find that RoO with other preferential trading partners are somewhat less restrictive than NAFTA RoO, although no compliance cost estimates are available for these other partners.

We compare the average unit value of exports of apparel products at the HS6 level to the United States and to other OECD member countries in 2001 and find that Mexican apparel exports to the United States have an average unit value 7.7 percent higher than comparable Mexican imports to other OECD members. This is consistent with a compliance cost of 7.7 percent and in line with the 9.2 percent compliance cost for textiles and apparel found by Carrère and de Melo. However, when we extend out methodology to 2005 trade, the premium on Mexican exports to the United States disappears. Applying the same methodology to CBTPA and ATPDEA countries yields premiums in excess of U.S. MFN tariff rates for 2005. This suggests the existence of substantial product heterogeneity at the 6-digit level, even when limiting analysis to OECD importers to control for quality differences. Because of these findings, we have chosen not to model a compliance cost in the simulations below.

\section{B. Quantitative Restraints}

The United States applied quantitative restrictions to imports from China and three non-WTO countries (Vietnam, Belarus, and the Ukraine) in 2005. The limits for nonWTO countries are set annually in negotiations between the United States and the respective governments, and in recent years quantitative limits for the smaller exporters have generally not been binding. ${ }^{13}$ The limits for Vietnam in 2005, however, remained important and will be analyzed below. The quantitative restraints on Chinese

\footnotetext{
${ }^{13}$ In 2005, no Ukrainian imports were restrained, and only $\$ 0.6$ million of Belarusian imports of glassfiber fabric sector were restrained. The restrictiveness of the Belarusian restraint was not estimated because of the low import value and the lack of relevant data.
} 
textiles and apparel in 2005 were imposed under the 2001 Chinese Protocol of Accession to the WTO, which allowed the United States and other countries to impose safeguards on Chinese textiles and apparel until December 31, 2008. The rapid increase in Chinese imports after the expiration of the ATC led to the establishment of 10 safeguards. All 10 safeguards filled at rates higher than 90 percent, and eight of the safeguards filled in their entirety, effectively preventing U.S. importers and retailers from receiving ordered goods. Disruptions and uncertainties associated with the safeguards led to the negotiation of a Memorandum of Understanding (MOU), a three-year agreement that established quotas on U.S. imports of selected textile and apparel products from China. The MOU went into effect on January 1, 2006.

We estimated the restrictiveness of Chinese safeguard sectors and Vietnamese sectors with binding restraints in 2005. Using a quota fill rate of 90 percent to indicate a binding quota, exports were restrained in 10 sectors from China and 10 sectors from Vietnam (Table 1). ${ }^{14}$ Total imports under Chinese safeguards during the safeguard periods totaled $\$ 1,646$ million, and imports in restrained sectors with Vietnam totaled $\$ 722$ million; together these accounted for 2.4 percent of total U.S. textile and apparel imports. ${ }^{15}$

\section{Estimating Chinese and Vietnamese Export Tax Equivalents}

To export to the United States, a firm in a quota-constrained country must buy an export license or otherwise obtain the right to use a portion of the quota. Given that quotas impose a cost on exporting firms analogous to an export tax, one common way to measure the restrictiveness of a quota is to compute an export tax equivalent (ETE), which measures the degree to which the quota increases the export price. More restrictive quotas lead to more valuable export licenses, which in turn produce higher ETEs. ${ }^{16}$

\footnotetext{
${ }^{14} \mathrm{An}$ alternative fill rate of 80 percent is sometimes employed in studies of trade restrictiveness. Using this alternative rate, only three additional sectors would be considered restrained. Because U.S. imports in these three sectors were low, the choice of fill rate has very little effect on trade-weighted ETEs and consequently has very little effect on the simulation results.

${ }^{15}$ U.S. imports under the safeguards accounted for approximately 5.9 percent of all textiles and apparel from China in 2005. On a calendar year basis, total U.S. imports in the 10 safeguard categories represented 14.7 percent of total U.S. imports of textiles and apparel from China, but most safeguards were not in place for the entire year.

${ }^{16}$ As noted by Krishna and Tan (1998), large U.S. retailers, which increasingly source directly from foreign suppliers, may extract a portion of these rents. The extent of such rent sharing is unknown; however, these ETEs may overstate import price increases and associated welfare reductions in the U.S. economy.
} 
Table 1. Restrained U.S. Imports: Change in Imports, Change in Unit Value, Tariff Rates, and ETEs, 2002-5

\begin{tabular}{|c|c|c|c|c|}
\hline Country and sector & $\begin{array}{l}\text { Change in } \\
\text { imports, } \\
2002-5^{\mathrm{a}}\end{array}$ & $\begin{array}{l}\text { Change in } \\
\text { unit value, } \\
2002-5^{\mathrm{a}}\end{array}$ & $\begin{array}{l}\text { Tariff } \\
\text { rate, } \\
2005^{\mathrm{b}}\end{array}$ & $\begin{array}{l}\text { ETE, } \\
2005\end{array}$ \\
\hline \multicolumn{5}{|l|}{ China } \\
\hline Combed cotton yarn (cat. 301, in kilograms) & 138.7 & 5.3 & 8.7 & 6.5 \\
\hline Hosiery (cat. 332/432/632pt, in dozen pairs) & 565.2 & -27.4 & 13.3 & 93.3 \\
\hline Cotton knit shirts and blouses (cat. 338/339, in dozens) & 214.9 & -59.7 & 15.5 & 57.6 \\
\hline Woven shirts, men's and boys' (cat. 340/640, in dozens) & 94.1 & -22.0 & 21.2 & 33.5 \\
\hline Cotton trousers (cat. 347/348, in dozens) & 239.6 & -49.0 & 15.4 & 38.6 \\
\hline Brassieres (cat. 349/649, in dozens) & 82.0 & -9.7 & 16.3 & 23.3 \\
\hline Underwear (cat. 352/652, in dozens) & 110.4 & -48.5 & 11.7 & 64.8 \\
\hline Other synthetic filament fabric (cat. 620, in square meters) & 380.6 & -57.5 & 9.3 & 35.3 \\
\hline Man-made fiber knit shirts (cat. 638/639, in dozens) & 113.4 & -41.4 & 29.2 & 34.5 \\
\hline Man-made fiber trousers (cat. 647/648, in dozens) & 52.5 & -34.8 & 22.6 & 33.1 \\
\hline \multicolumn{5}{|l|}{ Vietnam } \\
\hline Cotton coats (cat. 334/335, in dozens) & 129.9 & 62.2 & 10.5 & 38.6 \\
\hline Cotton knit shirts (cat. 338/339, in dozens) & 153.7 & 11.1 & 16.2 & 57.6 \\
\hline Woven shirts, men's and boys' (cat. 340/640, in dozens) & 260.4 & 26.5 & 20.5 & 33.4 \\
\hline Woven shirts, women's and girls' (cat. 341/641, in dozens) & 141.0 & 16.9 & 17.5 & 33.4 \\
\hline Cotton and man-made fiber skirts (cat. 342/642, in dozens) & 129.4 & 12.5 & 10.7 & 38.6 \\
\hline Cotton trousers, slacks, and shorts (cat. 347/348, in dozens) & 127.6 & 23.9 & 15.4 & 38.6 \\
\hline Swimwear (cat. 359S/659S, in kilograms) & 854.7 & 94.2 & 23.1 & 28.2 \\
\hline Other synthetic filament fabric (cat. 620, in square meters) & 21.0 & 16.8 & 1.3 & 35.3 \\
\hline Man-made fiber knit shirts (cat. 638/639, in dozens) & 163.0 & 41.5 & 29.7 & 34.5 \\
\hline Man-made fiber trousers (cat. 647/648, in dozens) & 154.9 & 55.8 & 22.5 & 33.1 \\
\hline \multicolumn{5}{|l|}{ Belarus } \\
\hline Heavy weight glass fiber fabric (cat. $622 \mathrm{~N}$, in square meters) & -34.1 & 28.3 & 6.7 & - \\
\hline
\end{tabular}

Source: Official statistics of the USDOC and USITC estimates.

${ }^{\mathrm{a}}$ Percentage changes.

${ }^{b}$ Based on the trade-weighted c.i.f. value of imports from each country (including both dutiable and dutyfree imports).

Under the ATC, the Chinese government auctioned a portion of export licenses in each restrained sector, and a number of studies have used these license prices to estimate ETEs. However, no export licenses were sold in 2005, because safeguards on Chinese imports were administered on a first-come-first-served basis. The Chinese government resumed its administration and auctions of export licenses 
under the MOU in 2006. Ten of the 21 MOU sectors were nearly identical to the corresponding 2005 safeguard sectors, so the January 2006 monthly average license prices were used as the best proxy for the 2005 license prices. ${ }^{17}$ The perunit production cost in each sector was estimated as the difference between the f.o.b. export price per unit to the United States and the per-unit price of an export license. ${ }^{18}$ The ETE in each sector was calculated as the license price divided by the estimated production cost. Table 1 presents estimates of Chinese ETEs, which range from 6.5-93.3 percent.

Vietnam does not report license prices, so the ETEs cannot be calculated as with China. ETEs could be estimated using the difference between export prices and production costs, but sector-specific estimates of production costs are not available. The availability of only one country with license prices also precludes crosscountry econometric estimates of ETEs as in USITC (2004). Lacking usable license price or production cost data, we have applied the Chinese ETEs to similar Vietnamese sectors (Table 2), and we perform sensitivity analysis of this choice in Section IV. Given Vietnamese export prices, these ETE values imply that Vietnamese production costs are on average 29.3 percent higher than Chinese costs, within the 20-30 percent range commonly given in apparel-industry trade journals. ${ }^{19}$

Trade data provide some evidence that Chinese and Vietnamese ETEs may have been similar in 2005, at least on average. Vietnamese imports in previously restrained sectors in Table 2 rose 55.1 percent in 2007 after restraints were removed. Chinese imports in previously restrained sectors rose 52.6 percent in 2005 after restraints were removed, though in a number of sectors this increase was limited because the United States applied safeguards in mid-2005. ${ }^{20}$ Of course this comparison is only suggestive, as the increase in Vietnamese trade in 2007 need

\footnotetext{
${ }^{17}$ License prices at the beginning of 2006 are likely to reflect the prices of 2005 licenses, had they been sold, because the set of restricted countries exporting to the United States did not change and the quota and MOU limits in 2006 are close to the quantities traded in 2005. January prices were used instead of the average prices in 2006 because prices in 2006 declined considerably after January. The price declines reflected low demand for licenses, because some U.S. importers switched to non-Chinese sources in 2006, likely due to the uncertainty associated with the safeguards in 2005 , although the initially higher quota prices indicate that importers were not able to change sources immediately.

${ }^{18}$ The f.o.b. price per unit is derived from official U.S. Customs data for customs value and quantity.

${ }^{19}$ See Just-style (2005) and Saheed (2006) for cross-country cost comparisons.

${ }^{20}$ This trade increase excludes socks, which were under safeguard for the entire 2005 , and limited to a 7.5 percent trade increase.
} 
Table 2. ETEs and Average Tariff Rates on Imports of Textiles and Apparel, Percent, 2005

\begin{tabular}{|c|c|c|c|c|}
\hline \multirow[b]{2}{*}{ Sector } & \multicolumn{4}{|c|}{ Sectoral price increase due to ETE froma } \\
\hline & $\begin{array}{l}\text { Average } \\
\text { tariff rate }\end{array}$ & China & Vietnam & Both \\
\hline All textile and apparel & 9.4 & 0.79 & 0.77 & 1.56 \\
\hline Textile mills & 4.4 & 0.04 & 0.00 & 0.04 \\
\hline Broadwoven fabric mills & 6.8 & 0.10 & 0.02 & 0.12 \\
\hline Narrow fabric mills & 3.7 & - & - & - \\
\hline Nonwoven fabric mills & 0.5 & - & - & - \\
\hline Knit fabric mills & 7.6 & - & - & - \\
\hline Yarn mills and textile finishing n.e.c. & 6.7 & 0.06 & - & 0.06 \\
\hline Thread mills & 4.4 & - & - & - \\
\hline Carpets and rugs & 1.6 & - & - & - \\
\hline Coated fabrics, not rubberized & 2.4 & - & - & - \\
\hline Tire cord & 1.3 & - & - & - \\
\hline Cordage and twine & 2.5 & - & - & - \\
\hline Textile goods n.e.c. & 2.0 & - & - & - \\
\hline Textile products & 6.4 & - & - & - \\
\hline Curtains and draperies & 9.3 & - & - & - \\
\hline House furnishings n.e.c. & 6.7 & - & - & - \\
\hline Textile bags & 4.6 & - & - & - \\
\hline Canvas and related products & 6.0 & - & - & 一 \\
\hline Pleating and stitching & 6.1 & - & - & - \\
\hline Fabricated textile products n.e.c. & 4.4 & - & - & - \\
\hline Apparel & 10.6 & 1.01 & 1.00 & 2.02 \\
\hline Women's hosiery & 4.0 & - & - & - \\
\hline Socks & 8.8 & 16.46 & - & 16.46 \\
\hline Apparel made from purchased materials & 10.7 & 0.76 & 1.01 & 1.78 \\
\hline
\end{tabular}

Source: Official statistics of the USDOC and USITC estimates.

${ }^{\mathrm{a}} \mathrm{A}$ dash indicates there were no quantitative restraints in a given sector.

${ }^{b}$ Based on trade-weighted c.i.f. values of imports (including both dutiable and duty-free imports).

not reflect the restrictiveness of 2005 restraints.

\section{ETEs in the Simulation Model}

To perform the simulation analysis in section 3, the ETEs for individual quotas must be combined to determine the ETE relevant to USAGE-ITC model sectors. For each model sector and foreign country, a trade-weighted average ETE is calculated using the ETE for each restrained subsector in that model sector, and an ETE of zero for all other trade in that sector. Table 2 gives the ETE for each model sector along with the trade-weighted average tariff rate, as percentages of total trade in each sector. 
ETEs are considerably lower than tariff rates in all sectors except for socks. ${ }^{21}$

The ETEs in 2005 are also considerably lower than those estimated in previous studies; for example, the average ETE for all textiles and apparel in this study is less than one-third of the average ETE reported in USITC (2004). ETEs declined chiefly because the share of imports that were restrained by quotas declined. The ETEs, however, remained important to the countries with quantitative restrictions and to their foreign competitors.

\section{Tariffs}

Textiles and apparel imports are subject to some of the highest U.S. tariffs, although a substantial portion now enter duty-free. The trade-weighted average ad valorem tariff on U.S. textile and apparel imports in 2005 was 9.4 percent (Table 2). In general, tariffs on textiles and apparel increase with each stage of manufacturing (i.e., the duty rates are usually higher on apparel than on its yarn or fabric inputs). The trade-weighted average tariffs were 4.4 percent for textile mills, 6.4 percent for textile products, and 10.6 percent for apparel. There is wide variation in tariff rates across products and partners, however, and tariffs for many common apparel articles were much higher than these average tariffs. ${ }^{22}$ Further, a significant portion of textile and apparel imports enter duty-free under FTAs and trade-preference programs. In 2005, 28.0 percent of total U.S. textile and apparel imports entered duty-free.

\section{Model Description}

The USAGE-ITC model is a large scale, dynamic CGE model of the United States developed by the Centre of Policy Studies and the Impact Project in collaboration with the U.S. International Trade Commission. ${ }^{23}$ USAGE-ITC is capable of conducting both static and dynamic CGE simulations, in the second

\footnotetext{
${ }^{21}$ The sock sector is officially denoted "hosiery, not elsewhere classified," and it includes a few small hosiery sectors in addition to socks, such as tights without soles and a few types of legwarmers. The women's hosiery sector includes all remaining types of hosiery, and excludes socks.

${ }^{22}$ For example, the 2005 Normal Trade Relations (formerly, MFN) duty rates on certain women's and girls' man-made fiber pants and blouses were 28.2 percent and 32.0 percent, respectively.

${ }^{23}$ USAGE-ITC is the latest in a series of models developed by the Centre of Policy Studies and the Impact Project over the last 30 years, beginning with the ORANI model and moving through to the dynamic MONASH model of Australia. For more detail on USAGE as a MONASH style of model, see Dixon and Rimmer (2002).
} 
case with recursive or forward-looking expectations. The dynamic components of USAGE-ITC involve, most importantly, the accumulation of various real and financial stocks and inter-temporal optimization by economic agents. USAGE-ITC distinguishes 523 commodities, 521 industries, 23 foreign regions, and a detailed handling of margins and taxes. ${ }^{24}$ Other features of the model include a detailed modeling of government expenditures and foreign liabilities.

USAGE-ITC follows the MONASH approach to CGE in being designed to conduct several broadly-defined types of simulation analysis. Historical simulations estimate the paths of unobservable variables over a historical period, such as changes in technology and consumer preferences. Forecasting simulations generate baselines consistent with outside macroeconomic forecasts and modelconsistent historical structural processes that are derived from the historical simulations. Policy simulations impose policy and other structural changes to calculate deviations from a forecast simulation baseline. In this paper, we report the results of both forecast and policy simulations. However, the historical simulation is essential to estimating trends that are applied to the forecast, as described below.

\section{A. Generating the Forecast and Policy Simulations}

In creating a forecast for the period 2005-11, we first create a complete dataset with 2005 values. These data come from a number of sources. Production data are based on the 2005 national income and product accounts published by the Bureau of the Census and on the 1992 input-output accounts from the Bureau of Economic Analysis. Trade flows and U.S. tariff rates for 2005 come from the U.S. Department of Commerce. Foreign tariff rates come from the UNCTAD TRAINS database.

Then we apply shocks to exogenous variables to represent movements from their 2005 values to their forecast values for 2011. Some exogenous values are taken from forecasts made by U.S. government agencies, including the Bureau of Economic Analysis, the U.S. Department of Agriculture and the Energy Information Administration. Trade policy changes are also included in the forecast, based on the final texts of U.S. free trade agreements provided by the USTR.

Shocks to technology, consumer preferences, foreign supply, and foreign demand for U.S. products are derived from extrapolations in the historical simulation. The historical simulation is used to generate information about

\footnotetext{
${ }^{24}$ Changes in foreign economies are not modeled endogenously but the model does incorporate changes in foreign productivity and shifts in foreign demand and supply schedules based on historical trends.
} 
conventionally unobservable variables. The approach involves (a) exogenizing many of the naturally endogenous variables (i.e., those usually explained in a CGE model), (b) imposing shocks on these variables calculated from data provided by the historical record, and (c) endogenizing the otherwise naturally exogenous or unobservable variables, allowing them to accommodate these data. For example, given information such as historical movements in relative commodity prices and household disposable income, it is possible to make a model-consistent estimate of the implied movements in consumer preferences over the same period.

Policy simulations are conducted by perturbing USAGE-ITC away from the forecast path by shocking policy variables. The results we report are calculated as the deviation, in percentage terms, away from the dynamic baseline forecast.

\section{B. Model Details}

\section{Demand and Production}

Consumers use a three stage procedure to allocate expenditure across goods that are differentiated by country of origin. In the first stage, expenditure for each sector is determined by a linear expenditure system, without regard to the origin of goods. ${ }^{25}$ In the second stage, consumers choose the relative expenditure on domestic and imported varieties of each good. The substitution possibility is specified with a constant elasticity of substitution (CES) parameter, commonly called the Armington elasticity. In the third stage, consumers allocate expenditure across multiple imported varieties, again with CES utility.

All sectors are assumed to be perfectly competitive. In the forecast, however, sectoral productivity may change due to exogenous shifts in a range of technologicalchange variables consistent with changes in the historical simulation. Firms engage in a multi-stage process that determines the relative expenditure on primary factors, domestic intermediates, and imported intermediates. Use of individual primary factors (labor, capital and land) is determined by a multi-level nesting structure. For each intermediate input, firms determine the expenditure on domestic and imported varieties using a CES function (the "Armington" approach). The primary factor bundle and the intermediate goods bundles are then combined to produce output using a CES function, for which parameters are chosen to allow very little substitution, resulting in a combination that is close to fixed proportions.

\footnotetext{
${ }^{25}$ The linear expenditure system allows consumers to change their relative preferences for goods and services at different levels of income.
} 


\section{Primary Factors}

Capital stocks evolve with a lagged adjustment process driven by dynamic investment behavior. Firms that increase output in response to increased product demand also increase their demand for capital. In the current period capital is in fixed supply, as investment augments the capital stock with a lag of one period. Labor is affected by population change and labor supply decisions. Adjustments in employment and wage rates in the policy simulation are driven by a sluggish adjustment mechanism. Wages rise if the path of employment in the policy simulation rises above its path in the forecast. Wages, however, are "sticky" so that adjustment occurs relatively slowly, leading to periods of sustained excess demand or supply in labor markets. The aggregate quantity of land is fixed in all periods, but the rental price can change according to changes in demand.

Capital and labor are mobile between sectors. Labor is immediately mobile between sectors and driven by a sticky adjustment mechanism based on relative inter-industry demands and the deviations in wages from their forecast levels. Capital is mobile in the sense that investment responds to industry prospects via rental rates and (thus) rates of return. Therefore, the evolution of capital stocks over time is the mechanism by which capital "moves" between industries.

\section{Balance of Payments and Trade}

In the forecast simulation, changes in the balance of payments are partly driven by macro forecasts and various trends observed in the historical simulation. As an example of an historical trend informing the forecast, it is assumed that between 2005 and 2011 the total U.S. foreign assets to GDP ratio will grow in the same way as it did between 1998 and 2005. In the absence of explicitly modeled foreign economies, this assumption is required to tie down US foreign investment in a sensible, empirically defendable way. With accumulation of foreign assets fixed relative to GDP, the forecast for the change in total U.S. foreign liabilities is determined largely by movements in current account balances, which are, in turn, driven by the net outcome of changes in the value of US exports, the value of US imports and the value of US dividend and interest payments on equity and debt, respectively.

USAGE recognizes 23 distinct foreign regions in trade. Each region includes an individual country or a group of countries to which the United States applies similar preferential trade policies. Inter-regional choice in exports and imports is handled by a demand nest that sits below the Armington nest. Variables that do not 
relate directly to goods trade are not split into multiple regions, but are distinguished only as domestic or foreign. This applies, for example, to international investment flows that feed into the evolution of the capital account in the balance of payments.

\section{Effects of Liberalization}

The simulation exercise proceeds in two steps. First, macro forecasts sourced from various U.S. official estimates and an analysis of various elements of national, international, and industry trends over the period 1992 to 2005 are used to inform a baseline projection of the U.S. economy from 2005 to 2011. This projection is used to illustrate the size of changes that would likely occur in the economy in the absence of changes to U.S. trade policy related to textiles and apparel. The baseline includes all pre-negotiated trade policy changes, such as the staging of tariff rates with FTA partners. However, to better examine the effects of quantitative restraints, the December 2008 expiration of Chinese quantitative restraints and the January 2007 removal of Vietnamese quantitative restraints have been excluded from the baseline. This allows welfare and sectoral effects of quantitative restraints to be analyzed with tariffs in the liberalization scenario.

Second, the model is used to simulate the removal of all import restraints in textiles and apparel. The results of this liberalization are presented as deviations from the projected trends. This liberalization has a number of components: it contains the elimination of RoO-driven foreign demand for U.S. textile input, elimination of all quantitative restraints, and duty-free access for all goods. The inputs to the liberalization scenarios for tariffs, ETEs, and RoO-driven demand are summarized in Tables 2 and 3.

To better illustrate the separate effects of RoO, quantitative restraints, and tariffs, the results of stepwise liberalization are presented below. First, the elimination of RoO-driven demand alone is presented, with detailed results in Table 6. Next, the combined effect of elimination of both $\mathrm{RoO}$ and quantitative restraints are considered, with the detailed results given in Table 7. Lastly, the effects of full liberalization of all RoO, quantitative restraints, tariffs are reported, along with detailed results in Table 8. Because changes in most macroeconomic effects are quite small in these liberalizations, we discuss these effects only in the full liberalization and focus on welfare and sectoral effects in the first two scenarios. We do not separately include tariff-only elimination, though this would look very 
Table 3. RoO-driven U.S. Foreign Demand as a Share of U.S. Exports by Sector and Partner, percent

\begin{tabular}{lrrrc}
\hline \multirow{2}{*}{ Sector } & \multicolumn{5}{c}{ Preferential trade partner or program } \\
\cline { 2 - 5 } & Mexico & Canada & ATPDEA & CBTPA \\
\hline Textile mills & 64.4 & 77.4 & 61.3 & 60.2 \\
$\quad$ Broadwoven fabric mills & 32.1 & 16.2 & 100.0 & 35.4 \\
Narrow fabric mills & 13.0 & 6.9 & - & - \\
Nonwoven fabric mills & 49.5 & 2.9 & 100.0 & 100.0 \\
Knit fabric mills & 100.0 & 0.3 & 100.0 & 54.8 \\
Yarn mills and textile finishing n.e.c. & 32.8 & 9.8 & 100.0 & 87.5 \\
Thread mills & 6.9 & 6.0 & - & - \\
Carpets and rugs & 4.4 & 10.1 & - & - \\
Coated fabrics, not rubberized & 46.4 & 5.1 & - & - \\
Textile goods n.e.c. & & & & \\
Textile products & 100.0 & 8.2 & - & - \\
House furnishings n.e.c. & 100.0 & 0.0 & - & - \\
Textile bags, canvas \& related products & 19.6 & 9.2 & - & - \\
Pleating and stitching & 100.0 & 2.4 & - & - \\
Auto appliqué, trim and embroideries & 94.0 & 61.2 & - & - \\
Fabricated textile products n.e.c. & & & & \\
Apparel & 93.2 & 0.0 & 100.0 & 100.0 \\
$\quad$ Women's hosiery & 100.0 & 0.0 & 100.0 & 100.0 \\
Socks & 100.0 & 100.0 & 100.0 & 100.0 \\
$\quad$ Apparel made from purchased materials & & & & \\
\hline
\end{tabular}

similar to the full liberalization, because preferential trade partners would starkly reduce or eliminate purchases of U.S. inputs with the elimination of their preferences, just as they would do with RoO elimination.

\section{A. Effects of Removing RoO Relative to the Baseline Forecast}

We first consider the effects on the textile and apparel industries of removing preferential RoO. Eliminating RoO-based foreign demand for U.S.-produced upstream textile and apparel products results in an overall decline in welfare and substantial contraction in the textiles and apparel sectors. GDP is expected to decline by $\$ 169.2$ million relative to baseline projections, while welfare falls by $\$ 695.6$ million (see Table 5). These losses are in sharp contrast to the gains resulting from joint liberalization of quantitative restraints and RoO (Section IV. B.) or from elimination of all barriers to trade in textiles and apparel (Section 
Table 4. Projected Percent Change in Textile and Apparel Sectors without Liberalization, 2005-11

\begin{tabular}{|c|c|c|c|c|c|}
\hline Sector & Employment & Output & Imports & Exports & $\begin{array}{c}\text { Household } \\
\text { price }^{\mathrm{a}}\end{array}$ \\
\hline All textile and apparel & -34.9 & -7.4 & 38.0 & 2.9 & 3.3 \\
\hline Textile mills & -30.9 & 2.3 & 9.8 & 26.9 & 4.4 \\
\hline Broadwoven fabric mills & -27.6 & 4.3 & 10.5 & 44.4 & 4.0 \\
\hline Narrow fabric mills & -17.8 & 23.0 & -10.4 & 34.1 & 2.9 \\
\hline Nonwoven fabric mills & -35.0 & -0.7 & 0.5 & -12.5 & 1.6 \\
\hline Knit fabric mills & -55.7 & -13.0 & 14.4 & 44.1 & 0.7 \\
\hline Yarn mills and textile finishing n.e.c. & -30.3 & -10.1 & -10.7 & 34.2 & 5.1 \\
\hline Thread mills & -37.1 & -15.7 & 0.5 & -6.1 & 4.2 \\
\hline Carpets and rugs & -26.3 & 7.4 & 8.3 & -15.7 & 5.2 \\
\hline Coated fabrics, not rubberized & -15.3 & 22.0 & 57.1 & 26.3 & 8.0 \\
\hline Tire cord & -30.8 & 4.2 & 24.8 & -28.9 & 7.9 \\
\hline Cordage and twine & -26.4 & 7.1 & 31.9 & -7.7 & 4.2 \\
\hline Textile goods n.e.c. & -29.6 & 9.2 & 13.8 & -32.1 & 4.7 \\
\hline Textile products & -28.7 & -1.3 & 28.8 & 21.3 & 3.8 \\
\hline Curtains and draperies & -31.4 & 0.7 & 5.6 & 38.4 & 2.6 \\
\hline House furnishings n.e.c. & -32.2 & -1.7 & 31.1 & 15.0 & 4.7 \\
\hline Textile bags & -28.1 & -1.9 & 34.0 & 27.6 & 4.7 \\
\hline Canvas and related products & -31.0 & -1.4 & 15.0 & -22.4 & 3.8 \\
\hline Pleating and stitching & -30.1 & 2.0 & 0.9 & 71.3 & 2.0 \\
\hline Auto appliqué and trim & -23.8 & -1.6 & $-^{\mathrm{c}}$ & 33.6 & 7.2 \\
\hline Embroideries & -33.7 & -10.7 & $-^{c}$ & 1.9 & 3.2 \\
\hline Fabricated textile products n.e.c. & -32.1 & -0.6 & 36.9 & 20.8 & 3.3 \\
\hline Apparel & -53.4 & -29.6 & 42.9 & -39.1 & -3.2 \\
\hline Women's hosiery & -50.6 & -2.0 & 40.2 & -51.3 & 0.5 \\
\hline Socks & -50.5 & -1.0 & 30.9 & -29.0 & -5.4 \\
\hline Apparel made from purchased materials & -53.8 & -33.4 & 43.1 & -38.8 & -5.3 \\
\hline \multicolumn{6}{|l|}{ Upstream sectors $^{\mathrm{b}}$} \\
\hline Cotton & -7.5 & 19.5 & 3.8 & 28.8 & 7.7 \\
\hline Cellulosic manmade fiber & -16.5 & 3.4 & 1.1 & 20.1 & 8.3 \\
\hline Synthetic fiber & -14.5 & -2.0 & 3.1 & 17.3 & 8.2 \\
\hline Textile machines & -30.9 & 20.1 & 7.3 & 2.5 & 8.1 \\
\hline \multicolumn{6}{|l|}{ Downstream sectors ${ }^{\mathrm{b}}$} \\
\hline Public building furniture & 25.0 & 66.0 & 46.7 & 46.7 & 8.5 \\
\hline Entire U.S. economy & 6.9 & $28.7^{\mathrm{d}}$ & 42.7 & 39.9 & 9.8 \\
\hline
\end{tabular}

${ }^{a}$ The household price is the share-weighted average price of imported and domestic products purchased by households.

${ }^{\text {b}}$ These categories include all sectors with at least a 1 percent increase or decrease in output after liberalization (see Table 4).

'There were no imports in these categories in 2005 , so percentage changes cannot be calculated.

${ }^{\mathrm{d}}$ Projected change in U.S. gross output is 28.7 percent; projected change in U.S. GDP is 21.7 percent. 
Table 5. Effects of Partial and Full Liberalizations on GDP and Welfare, Relative to Projections, million dollars, 2011

\begin{tabular}{lcc}
\hline \multicolumn{1}{c}{ Type of liberalization } & Change in GDP & Change in welfare \\
\hline RoO-driven demand reductions only & -169.2 & -695.6 \\
RoO and quantitative restraints liberalization & 117.7 & 1169.8 \\
Full liberalization & 800.2 & 2041.7 \\
Quantitative restraints sensitivity analysis & & \\
$\quad$ Chinese ETE reduction only & 88.2 & 895.5 \\
$\quad$ Chinese plus low Vietnamese ETEs & 187.4 & 1378.6 \\
$\quad$ Chinese plus preferred Vietnamese ETEs & 287.7 & 1869.8 \\
$\quad$ Chinese plus high Vietnamese ETEs & 388.8 & 2368.2 \\
Tariff liberalization, without demand reduction & 766.5 & 829.8 \\
\hline
\end{tabular}

Note: The effects of the partial liberalizations may not sum to the full liberalization because of rounding and because of minor interaction effects absent from the partial liberalizations.

IV.C.). Sectoral effects are given in Table 6.

Liberalizing $\mathrm{RoO}$ is quite adverse to U.S. economic welfare for a simple reason: a substantial source of demand for these industries disappears. Those industries most affected by RoO liberalization are those whose demand curves move the most, and this is a function of (a) the size of the affected exporting sector, and (b) the proportion of that source of demand that is generated by RoO. For example, the hardest-hit industry from RoO liberalization is knit fabrics, an industry characterized by a high export share in sales (44.4 percent), a large RoO share in exports (estimated to be between 49.5 percent and 100 percent for all export regions except Canada), and the largest RoO shocks falling on those export regions with high shares in the industry's total exports (for example, CAFTA comprises 48 percent of the industry's export demand, and this source of demand is entirely RoO-driven). Employment changes generally reflect industry results, as expected, but typically with slightly higher percentage changes that reflect the stickiness of capital stocks as industries decline. ${ }^{26}$

\footnotetext{
${ }^{26}$ The employment change is similar to the output change in all sectors except house furnishings. In house furnishings, employment increases by 3.4 percent while output declines by 1.1 percent. This result occurs because 21.1 percent of house furnishings are produced by workers in the broad fabric sector. The large contraction in the broad fabric sector sharply reduces production of house furnishings by workers in the broad fabric sector; thus employment in the house furnishings industry must increase even though the combined output in the house furnishings sector contracts slightly. Similar effects are seen in the following liberalizations in women's hosiery, because 55.0 percent of the output of women's hosiery is produced by workers in the sock sector
} 
Table 6. Effects of RoO Liberalization, Relative to Projections, percent change, 2011

\begin{tabular}{lrrrrc}
\hline \multicolumn{1}{c}{ Sector } & Employment & Output & Imports & Exports & $\begin{array}{c}\text { Household } \\
\text { price }\end{array}$ \\
\hline All textile and apparel & -8.4 & -7.4 & -0.9 & -48.3 & -0.1 \\
Textile mills & -12.3 & -10.4 & -6.8 & -45.1 & -0.1 \\
Broadwoven fabric mills & -20.5 & -13.8 & -9.3 & -56.3 & -0.4 \\
Narrow fabric mills & -17.5 & -16.7 & -4.5 & -20.0 & 0.0 \\
Nonwoven fabric mills & -0.6 & -1.0 & -5.9 & -3.5 & 0.0 \\
Knit fabric mills & -44.0 & -41.3 & -24.4 & -78.6 & -0.3 \\
Yarn mills and textile finishing n.e.c. & -13.8 & -13.7 & -14.1 & -47.8 & -0.4 \\
Thread mills & -15.0 & -13.8 & -3.8 & -42.6 & -0.2 \\
Carpets and rugs & -0.1 & -0.1 & -0.1 & -3.5 & -0.1 \\
Coated fabrics, not rubberized & -0.6 & -0.7 & -0.6 & -3.1 & 0.0 \\
Textile goods n.e.c. & 0.2 & -0.6 & -0.3 & -7.8 & 0.0 \\
Textile products & -2.9 & -3.8 & -0.5 & -43.0 & -0.1 \\
House furnishings n.e.c. & 3.4 & -1.1 & -0.1 & -22.6 & 0.0 \\
Textile bags, canvas \& related products & -0.3 & -0.4 & -0.3 & -14.2 & -0.1 \\
Pleating and stitching & -2.8 & -2.8 & -2.1 & -15.8 & -0.2 \\
Auto appliqué, trim and embroideries & -1.3 & -1.4 & -0.4 & -26.5 & -0.1 \\
Fabricated textile products n.e.c. & -21.0 & -18.8 & -1.8 & -55.9 & -0.4 \\
Apparel & -10.4 & -8.7 & -0.5 & -87.1 & -0.1 \\
Women's hosiery & -0.3 & -2.5 & -0.8 & -72.3 & -0.1 \\
Socks & -5.7 & -5.8 & -0.7 & -89.2 & -0.1 \\
Apparel made from purchased materials & -11.4 & -9.8 & -0.5 & -87.6 & 0.0 \\
Upstream sectors ${ }^{\mathrm{b}}$ & & & & & \\
Cotton & -6.9 & -6.2 & -20.6 & 2.0 & 0.0 \\
Manmade fibers & -2.7 & -4.0 & -8.1 & 6.7 & 0.0 \\
Textile machines & -2.4 & -2.4 & -4.2 & 1.3 & 0.0 \\
Downstream sectors ${ }^{\mathrm{b}}$ & & & & & \\
Public building furniture & 0.4 & 0.4 & 0.0 & 2.1 & 0.0 \\
Entire U.S. economy & 0.0 & 0.0 & 0.0 & 0.0 & 0.0 \\
\hline
\end{tabular}

${ }^{a}$ The household price is the share-weighted average price of imported and domestic products purchased by households.

${ }^{\mathrm{b}}$ These categories include all sectors with at least a 1 percent increase or decrease in output.

'There were no imports in these categories in 2005, so percentage changes cannot be calculated.

${ }^{\mathrm{d}}$ Projected change in U.S. gross output is -0.015 percent; projected change in U.S. GDP is -0.001 percent.

\section{B. Effects of Removing RoO and Quantitative Restraints Relative to the Baseline Forecast}

When the removal of quantitative restraints is added to the RoO liberalization scenario, industry output results are generally not changed, with the exception of 
Table 7. Effects of RoO and Quantitative Restraint Liberalization, Relative to Projections, percent change, 2011

\begin{tabular}{lrrrrr}
\hline \multicolumn{1}{c}{ Sector } & Employment & Output & Imports & Exports & $\begin{array}{c}\text { Household } \\
\text { price }^{\mathrm{a}}\end{array}$ \\
\hline All textile and apparel & -8.5 & -7.6 & -0.4 & -48.3 & -0.3 \\
Textile mills & -12.5 & -10.5 & -6.8 & -45.0 & -0.1 \\
Broadwoven fabric mills & -20.7 & -13.8 & -9.0 & -56.3 & -0.4 \\
Narrow fabric mills & -17.5 & -16.8 & -4.4 & -20.0 & 0.0 \\
Nonwoven fabric mills & -0.6 & -1.1 & -5.9 & -3.5 & 0.0 \\
Knit fabric mills & -44.2 & -41.6 & -24.9 & -78.6 & -0.3 \\
Yarn mills and textile finishing n.e.c. & -14.2 & -14.1 & -14.7 & -47.7 & -0.4 \\
Thread mills & -15.1 & -13.9 & -3.9 & -42.6 & -0.2 \\
Carpets and rugs & -0.1 & -0.1 & -0.1 & -3.5 & -0.1 \\
Coated fabrics, not rubberized & -0.6 & -0.7 & -0.7 & -3.1 & 0.0 \\
Textile goods n.e.c. & 0.2 & -0.6 & -0.3 & -7.8 & 0.0 \\
Textile products & -2.9 & -3.8 & -0.5 & -43.0 & -0.1 \\
House furnishings n.e.c. & 3.4 & -1.1 & -0.1 & -22.6 & 0.0 \\
Textile bags, canvas \& related products & -0.3 & -0.4 & -0.3 & -14.2 & 0.0 \\
Pleating and stitching & -2.8 & -2.7 & -2.1 & -15.6 & -0.2 \\
Auto appliqué, trim and embroideries & -1.3 & -1.3 & -0.4 & -26.4 & -0.1 \\
Fabricated textile products n.e.c. & -21.0 & -18.8 & -1.8 & -55.9 & -0.4 \\
Apparel & -10.6 & -9.2 & 0.2 & -87.0 & -1.7 \\
Women's hosiery & 2.4 & -2.7 & -0.8 & -72.4 & -0.1 \\
Socks & -9.7 & -9.9 & 7.8 & -89.1 & -4.6 \\
Apparel made from purchased materials & -11.4 & -10.2 & 0.1 & -87.6 & -0.6 \\
Upstream sectors & & & & & \\
Cotton & -7.1 & -6.3 & -21.0 & 2.1 & 0.0 \\
Manmade fibers & -2.8 & -4.2 & -8.2 & 6.6 & 0.0 \\
Textile machines & -2.6 & -2.6 & -4.4 & 1.2 & 0.0 \\
Downstream sectors & & & & & \\
Public building furniture & 0.4 & 0.4 & 0.0 & 2.0 & 0.0 \\
Entire U.S. economy & 0.0 & $0.0^{\mathrm{d}}$ & 0.0 & -0.1 & 0.0 \\
\hline The hous & & & & &
\end{tabular}

${ }^{a}$ The household price is the share-weighted average price of imported and domestic products purchased by households.

${ }^{\mathrm{b}}$ These categories include all sectors with at least a 1 percent increase or decrease in output.

${ }^{c}$ There were no imports in these categories in 2005 , so percentage changes cannot be calculated.

${ }^{\mathrm{d}}$ Projected change in U.S. gross output is -0.017 percent; projected change in U.S. GDP is 0.001 percent.

socks (Table 7). The effect on GDP and welfare switch from negative to positive, with GDP rising by $\$ 118$ million and welfare by $\$ 1,170$ million in response to liberalization. When simulated separately, the removal of Chinese quotas generates a gain of $\$ 895$ million, and removal of Vietnamese quotas using our preferred 
Table 8. Effects of Full Liberalization, Relative to Projections, percent change, 2011

\begin{tabular}{lrrrrr}
\hline \multicolumn{1}{c}{ Sector } & Employment & Output & Imports & Exports & $\begin{array}{c}\text { Household } \\
\text { price }^{\mathrm{a}}\end{array}$ \\
\hline All textile and apparel & -9.5 & -9.0 & 3.2 & -47.8 & -1.2 \\
Textile mills & -15.0 & -12.0 & 0.4 & -44.6 & -0.5 \\
Broadwoven fabric mills & -24.2 & -16.3 & 7.1 & -55.8 & -0.9 \\
Narrow fabric mills & -17.3 & -16.7 & -3.4 & -19.9 & -1.2 \\
Nonwoven fabric mills & -0.4 & -1.0 & -5.5 & -3.2 & -0.1 \\
Knit fabric mills & -46.2 & -44.1 & -19.0 & -78.0 & -0.7 \\
Yarn mills and textile finishing n.e.c. & -17.3 & -17.1 & -7.7 & -47.3 & -1.1 \\
Thread mills & -15.9 & -14.7 & -0.3 & -42.1 & -1.3 \\
Carpets and rugs & -0.2 & -0.2 & 1.0 & -2.9 & -0.1 \\
Coated fabrics, not rubberized & -1.1 & -1.2 & 2.8 & -2.1 & 0.0 \\
Textile goods n.e.c. & -0.1 & -1.0 & 1.8 & -7.5 & -0.1 \\
Textile products & -3.3 & -4.3 & 2.8 & -42.0 & -1.3 \\
House furnishings n.e.c. & 3.7 & -1.6 & 2.9 & -21.0 & -1.7 \\
Textile bags, canvas \& related products & -3.0 & -2.9 & 6.6 & -12.3 & -1.4 \\
Pleating and stitching & -3.0 & -2.8 & 2.6 & -13.8 & -0.9 \\
Auto appliqué, trim and embroideries & -1.2 & -1.1 & -0.7 & -24.7 & -0.2 \\
Fabricated textile products n.e.c. & -20.9 & -18.8 & -0.4 & -55.2 & -1.4 \\
Apparel & -10.1 & -11.1 & 3.4 & -86.8 & -3.4 \\
Women's hosiery & 2.7 & -2.9 & 2.7 & -72.1 & -0.1 \\
Socks & -11.1 & -11.6 & 12.0 & -88.9 & -6.7 \\
Apparel made from purchased materials & -10.8 & -12.3 & 3.3 & -87.3 & -3.6 \\
Upstream sectors ${ }^{\mathrm{b}}$ & & & & & \\
Cotton & -8.3 & -7.5 & -24.7 & 2.5 & 0.1 \\
Manmade fibers & -3.4 & -5.0 & -8.9 & 7.4 & 0.0 \\
Textile machines & -3.2 & -3.2 & -5.2 & 1.1 & 0.2 \\
Downstream sectors ${ }^{\mathrm{b}}$ & & & & & \\
Public building furniture & 1.2 & 1.1 & -0.1 & 6.2 & 0.1 \\
Entire U.S. economy & 0.0 & 0.0 & 0.1 & 0.1 & 0.1 \\
\hline
\end{tabular}

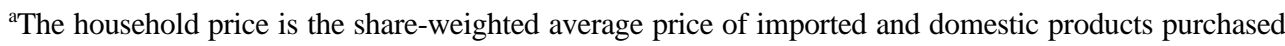
by households.

${ }^{\mathrm{b}}$ These categories include all sectors with at least a 1 percent increase or decrease in output.

'There were no imports in these categories in 2005, so percentage changes cannot be calculated.

${ }^{\mathrm{d}}$ Projected change in U.S. gross output is -0.01 percent; projected change in U.S. GDP is 0.005 percent.

measure of ETEs yields $\$ 974$ million. Vietnamese quantitative restraints have a larger effect on welfare despite affecting a smaller share of U.S. imports because Vietnamese ETEs are highest in the most heavily traded sectors.

Although available trade data suggest that on average Vietnamese ETEs were close to Chinese ETEs, no precise estimates of Vietnamese ETEs were possible, so 
we have included sensitivity analysis in Table 5 . The two alternative simulations assumed (a) Vietnamese ETEs 50 percent less than, and (b) 50 percent larger than, those estimated. In scenario (a), welfare gains to the US economy were 49.6 percent of those in the benchmark scenario. In the case of scenario (b), welfare gains were 51.1 percent of those in the benchmark scenario. These results are close to linear in assumed magnitude of Vietnamese ETEs. ${ }^{27}$

Returning to the preferred specification, for the majority of industries, granting greater market access to foreign competitors while also facing RoO-driven demand reductions causes a small additional decline in output. The hardest hit industry in this case is socks (-9.9 percent compared to -5.8 percent in Table 6), because this sector faces the removal of the most binding import quota. In contrast, apparel, which faces the second most binding quota, declines by only marginally more than under RoO liberalization alone, because the price effects of these quotas are quite small relative to sock quotas. In the alternative simulations, sectoral effects (not reported) were also nearly linear in the magnitude of ETEs.

\section{Effects of Full Liberalization Relative to the Baseline Forecast}

Full liberalization of textiles and apparel is expected to raise GDP and welfare more than $\mathrm{RoO}$ and quantitative restraints liberalization, either separately or combined. With full liberalization, welfare in 2011 rises by $\$ 2,041$ million compared to the baseline simulation (Table 5). As previously noted, RoO elimination would reduce welfare by $\$ 696$ million. The elimination of quantitative restraints alone would increase welfare by $\$ 1,869$ million. Efficiency gains from the removal of tariffs would improve welfare by $\$ 830$ million. Of course, the complete erosion of tariff preferences would result in the equivalent foreign demand reduction that we see in the RoO liberalization above; thus, on net tariff removal would increase welfare by only a small amount. There would be a similar though much smaller decrease in foreign demand from the removal of quantitative restraints.

The change in GDP for each scenario is strongly influenced by relative changes in imports and exports. For example, elimination of Vietnamese quotas increases GDP considerably more than does the elimination of Chinese quantitative restraints because China is a larger trade partner than Vietnam, so that the elimination of

\footnotetext{
${ }^{27}$ Taking the share of these sectors in US expenditure, adjusting for the import share in this expenditure and then the share of Vietnam in each sector, we generate numbers that are too small to create significant non-linearities in the general equilibrium system.
} 
Chinese quantitative restraints results in a correspondingly larger increase in imports and a smaller increase in GDP.

The removal of all barriers in textiles and apparel trade has a relatively minor effect on other macroeconomic variables. The final row of Table 8 shows that employment, production, imports, and exports in the overall economy change by 0.1 percent or less as a result of liberalization, relative to the 2011 baseline projection. This, in large part, reflects the relatively small share of the U.S. textiles and apparel sector in U.S. GDP, and the fact that these sectors are characterized by a higher-thanaverage labor share in production, allowing reallocation of primary factors to occur relatively quickly.

The sectoral effects of liberalization in Table 8 are chiefly determined by the incidence of preferential RoO. In the sectors that are less subject to preferential $\mathrm{RoO}$, the estimated changes from the policy liberalization are small relative to the projected changes based on industry trends. In these sectors, liberalization would cause small declines in domestic output and employment and a small increase in imports, relative to the 2011 baseline projection. Liberalization would also result in a domestic price decline, which would limit the decline in U.S. exports by making them more competitive in world markets. In contrast, sectors with greater exposure to RoO have large responses to full liberalization, though textile and apparel sectors differ. In textile sectors subject to preferential $\mathrm{RoO}$, the reduction in foreign demand accounts for almost all of the total reduction in output. In apparel sectors, tariffs and ETEs are higher and account for more of the output decline than in textiles, but the elimination of preferential RoO still accounts for at least 46 percent of the output decline in each apparel sector. The decline in employment for these sectors is generally close to the decline in output.

Examining the effect of liberalization on exports further highlights the effect of preferential RoO (Table 6). The liberalization of quantitative restraints and tariffs both lead to small estimated increases in U.S. exports due largely to declining U.S. production prices and, therefore, a small real depreciation. In contrast, elimination of RoO-based compliance costs and foreign demand leads to very large estimated export reductions in sectors directly affected by preferential RoO.

Aside from textiles and apparel industries, only cotton, textiles machines, and manmade fibers experience a decline in output of more than 1 percent as a result of the liberalization. In all these cases, the output shares of these industries are biased heavily toward intermediate demand in the textiles and apparel sectors, and so declines in those downstream industries are passed back to their suppliers. Consistent 
with the textile and apparel results, these upstream sectors are also more affected by the elimination of RoO-based foreign demand than by the elimination of tariffs or quotas. In these sectors, foreign demand reduction accounts for at least 79 percent of the output decline in each case. The only downstream sector to increase output more than 1 percent is public building furniture. This sector is less affected by $\mathrm{RoO}$ and experiences a smaller overall change in output.

\section{Conclusion}

This paper has analyzed the effect of textile and apparel import barriers and regulations on U.S. welfare and sectoral activity. We find that the effects of quantitative restraints have declined after the ATC, although remaining quantitative measures in 2005 still imposed about 20 percent of the welfare cost estimated in pre-2005 studies of these barriers. Tariffs in these sectors remain high and continue to reduce welfare. This paper includes a new and careful examination of preferential RoO-based foreign demand in these sectors, and finds that the effect of foreign demand is substantial for textile and apparel output, trade, and employment.

Elimination of quantitative restraints, tariffs, and preferential RoO differ markedly from one another in their effect on welfare and other macroeconomic variables. Eliminating only RoO would reduce GDP by $\$ 169$ million and welfare by $\$ 696$ million, as U.S. textile and apparel manufactures lose significant sources of export demand. Adding elimination of quantitative restraints leads to improvement in both GDP (\$117 million) and welfare (\$1170 million), while worsening textile and apparel output decline only slightly ( 0.2 percent). Removal of all textile and apparel barriers and $\mathrm{RoO}$ is estimated to increase net U.S. welfare by $\$ 2.04$ billion while decreasing U.S. textile and apparel output by an additional 1.4 percent. Elimination of quantitative restraints provides more than twice the welfare gain from the elimination of tariffs, while RoO-driven demand reductions reduce welfare and account for 82 percent of the output loss from complete liberalization of textile and apparel trade.

A similarly large output loss would also be part of any tariff liberalization that encouraged preferential trade partners to reduce purchases of U.S. inputs as their preference margins were eroded. This elimination of foreign demand also reduces the estimated welfare benefits from tariff liberalization by four-fifths. These results highlight the large effects preferential textile and apparel RoO have on both U.S. welfare and sectoral activity, and reinforce the importance of accounting for both RoO-based foreign demand. 


\section{Acknowledgements}

The views expressed in this paper are those of the authors and do not necessarily represent those of the U.S. International Trade Commission or the individual Commissioners. We thank Andrea Boron, Peter Dixon, Kim Freund, Peter Minor, Maureen Rimmer, Dean Spinanger, and participants at the 2007 Conference on Global Economic Analysis for helpful suggestions.

Received 30 June 2007, Revised 7 March 2008, Accepted 8 April 2008

\section{References}

Anson, José, Olivier Cadot, Antoni Estevadeordal, Jaime de Melo, Akiko SuwaEisenmann, and Bolormaa Tumurchudur (2005) "Rules of Origin in North-South Preferential Trading Arrangements with an Application to NAFTA." Review of International Economics, 13(3), 501-517.

Carrère, Céline and Jaime de Melo (2004) "Are Different Rules of Origin Equally Costly? Estimates from NAFTA.” CEPR Discussion Paper No. 4437. London: Centre for Economic Policy Research.

Cadot, Olivier, Céline Carrère, Jaime de Melo, and Alberto Portugal-Pérez.

Center on Globalization, Governance, and Competitiveness (2006) "North Carolina in the Global Economy 2006." http://www.soc.duke.edu/NC GlobalEconomy/textiles/ overview.php

Dixon, Peter B, and Maureen T. Rimmer (2002) Dynamic General Equilibrium Modelling for Forecasting and Policy: a Practical Guide and Documentation of MONASH. Contributions to Economic Analysis 256. Amsterdam: North Holland.

de Melo, Jaime and David Tarr (1990) "Welfare Costs of U.S. Quotas in Textiles, Steel and Autos." Review of Economics and Statistics, 72(3), 489-497.

Estevadeordal, Antoni and Kati Suominen (2006) "Mapping and Measuring Rules of Origin Around the World." In The Origin of Goods: Rules of Origin in Regional Trade Agreements, ed. Olivier Cadot, Antoni Estevadeordal, Akiko Suwa-Eisenmann, and Thierry Verdier, 69-114. New York: Oxford University Press.

Just-style (2005) "Vietnam: Textile Industry Steps up Expansion Plans." (February 14). http://www.just-style.com/article.aspx?id=72473n \&lk=s

Krishna, Kala and L.H. Tan (1998) Rags and Riches: Implementing Apparel Quotas under the Multi-Fibre Arrangement. Ann Arbor, MI: University of Michigan Press, 1998.

Reinert, Kenneth (1993) "Textile and Apparel Protection in the United States: A General Equilibrium Analysis." World Economy, 16(3), 359-376.

Saheed, A.H.H. (2006) "Outlook of Major Apparel Exporting Countries of Asia: Vietnam" Asian Textile Business 615, 63-66. http://www.allbusiness.com/asia/ 
1084481-1.html

Spinanger, Dean (1999) “Textiles Beyond the MFA Phase-Out.” World Economy, 22(4), 455-476.

U.S. International Trade Commission (1995) The Economic Effects of Significant U.S. Import Restraints, First Biannual Update. USITC Publication 2935. Washington, DC: USITC.

(1999a) The Economic Effects of Significant U.S. Import Restraints, Second Update 1999. USITC Publication 3201. Washington, DC: USITC.

- (1999b) Production Sharing: Use of U.S. Components and Materials in Foreign Assembly Operations, 1995-1998. USITC Publication 3265. Washington, DC: USITC.

(2002) The Economic Effects of Significant U.S. Import Restraints, Third Update 2002. USITC Publication 3519. Washington, DC: USITC.

(2004) The Economic Effects of Significant U.S. Import Restraints, Fourth Update 2004. USITC Publication 3701. Washington, DC: USITC.

- (2007) The Economic Effects of Significant U.S. Import Restraints, Fifth Update 2007. USITC Publication 3906. Washington, DC: USITC.

Walmsley, Terrie and Thomas Hertel (2001) "China's Accession to the WTO: Timing is Everything." World Economy, 24(8), 1019-1049.

Walkenhorst, Peter (2005) "Quantitative Assessments of Textiles Trade Liberalization: A Survey." Journal of Economic Integration, 20(1), 139-157. 